\title{
Obesity and Breast Cancer: Association of Serum Adiponectin, Leptin, and Adiponectin-Leptin Ratio as Risk Biomarkers
}

\begin{abstract}
Introduction: Obesity has been associated with the development of breast cancer. The objectives were to study the association of serum adiponectin, serum leptin, and adiponectin-leptin ratio (ALR) in patients with breast cancer and matched controls, and to study their relationship with the various clinicopathological characteristics of breast cancer. Materials and Methods: A prospective, hospital-based case-control study was conducted on 40 patients with a first-confirmed histopathology diagnosis of breast cancer and 40 controls comprising individuals without a history of cancer simultaneously recruited from the health examination clinics during the same study period. Serum adiponectin and leptin concentrations were measured in a single run using commercially available kits (Human ADP/Acrp30 [adiponectin] enzyme-linked immune-sorbent assay [ELISA] kit and Human Leptin ELISA kit, Elabscience Biotechnology Co., Ltd) according to the manufacturer's instructions. Results: Serum adiponectin levels were reduced significantly in breast cancer patients, in comparison to controls $(P=0.04)$, while serum leptin levels were increased significantly in breast cancer patients, in comparison to controls $(P=0.03)$. ALR was significantly lower in breast cancer cases, in comparison to controls $(P=0.05)$. There was no correlation between receptor status (estrogen receptor, progesterone receptor, Her $2 /$ neu), aggressiveness of disease in terms of tumor size, nodal metastases, stage, tumor grade, and serum adiponectin levels, leptin levels, or ALR. Body mass index was negatively correlated with serum adiponectin levels and ALR ( $r=0.33, P=0.03 ; r=0.39, P=0.01$, respectively) and positively correlated with serum leptin levels $(r=0.34, P=0.02)$. Conclusion: In summary, our results suggest that low serum adiponectin levels, ALR, and high serum leptin levels are associated with breast cancer.
\end{abstract}

Keywords: Adiponectin, adiponectin-leptin ratio, breast cancer, leptin

\section{Introduction}

Obesity has been associated with the development of breast cancer. ${ }^{[1]}$ The main underlying mechanisms that link obesity to cancer development and progression include abnormalities of insulin resistance and the insulin-like growth factor system, impact of adiposity on the biosynthesis and bioavailability of endogenous sex hormones, obesity-induced low-grade chronic systemic inflammation, and alterations in the levels of adipocyte-derived growth factors. ${ }^{[2]}$

Adiponectin, a 244-amino acid protein hormone, also known as AdipoQ, Acrp30 (adipocyte complement-related protein of $30 \mathrm{kDa}$ ), apM1 (gene product of the adipose most abundant gene transcript-1), and GBP28 (gelatin-binding protein-28), is the most abundant adipocyte-derived factor, with insulin-sensitizing, anti-inflammatory, and

This is an open access journal, and articles are distributed under the terms of the Creative Commons Attribution-Non Commercial-ShareAlike 4.0 License, which allows others to remix, tweak, and build upon the work non-commercially, as long as appropriate credit is given and the new creations are licensed under the identical terms.

For reprints contact: reprints@medknow.com antiatherogenic properties. ${ }^{[3]}$ Leptin, a peptide hormone produced by the ob gene of adipocytes, increases in concert with adiposity and has been shown to have mitogenic effects on epithelial cells and to promote cellular proliferation, migration, and invasion in breast cancer cell lines, properties potentially increasing breast cancer risk and progression. ${ }^{[4]}$ Studies have examined and considered the ratio of these adipokines to be more important in breast cancer than their absolute concentrations. ${ }^{[5]}$

The objectives of the study were to determine the association of serum adiponectin, serum leptin, and adiponectin-leptin ratio (ALR) in patients with breast cancer and matched controls, and to study their relationship with the various clinicopathological characteristics of breast cancer.

How to cite this article: Danthala M, Rajesh GR, Gundeti S, Raju GS, Chandran P, Srinivas ML. Obesity and breast cancer: Association of serum adiponectin, leptin, and adiponectin-leptin ratio as risk biomarkers. Indian J Med Paediatr Oncol 2018;39:292-6.

\section{Madhav Danthala, Gogulamudi Ratna Rajesh ${ }^{1}$, Sadashivudu Gundeti, Gottumukkala Suryanarayana Raju², Priscilla Chandran ${ }^{1}$, Maddali Lakshmi Srinivas}

Departments of Medical Oncology, 'Biochemistry and ${ }^{2}$ Surgical Oncology, Nizam's Institute of Medical Sciences, Panjagutta, Hyderabad, Telangana, India

Address for correspondence Dr. Madhav Danthala, Flat, 03, H.no 8-2-402/3/2, Banjara Petals Apartment, Road Number 5 Banjara Hills, Hyderabad - 500034 Telangana, India E-mail: docdanthala@ hotmail.com

Access this article online Website: www.ijmpo.org DOI: 10.4103/ijmpo.ijmpo_203_16 Quick Response Code:

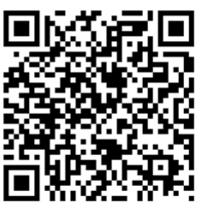




\section{Materials and Methods}

\section{Patients}

A prospective, hospital-based case-control study was conducted on 40 patients with a first-confirmed histopathology diagnosis of breast cancer before treatment commencement and 40 controls comprising individuals without a history of cancer simultaneously recruited from the health examination clinics during the same study period. Data on the status of estrogen receptor (ER), progesterone receptor (PR), and Her-2/Neu were obtained. One control case was matched to each case by age, menopausal status, date of enrollment ( \pm 3 months), and duration of fasting $( \pm 4 \mathrm{~h})$. Cases not histologically proven, male breast cancer patients, patients with previous history of breast or other cancers, history of diabetes mellitus on treatment, and subjects who reported a recent (within the previous $1-6$ months) weight gain or loss of $5 \%$ or more of their current weight were excluded from the study.

\section{Collection of questionnaire data}

The study was conducted in accordance with the Declaration of Helsinki, and the study protocol was reviewed by the Institutional Ethics Committee. All patients gave written informed consent and underwent a personal interview. Data were collected on sociodemographic characteristics, menstrual and reproductive history, menopausal status, lifestyle behavior, and medical history as well as family history of breast and other cancers. Menopausal status was defined as last menstruation after 1 year free of menstrual cycle and no attempt was made to distinguish between women with artificial and those with natural menopause.

\section{Assay principle}

A $10 \mathrm{ml}$ blood sample for measurement of serum adiponectin and leptin was collected in vacutainer tubes (EDTA-treated), and all tubes were centrifuged at $4^{\circ} \mathrm{C}$ for collection of serum. These were stored at $-20^{\circ} \mathrm{C}$ until analysis. Serum adiponectin and leptin concentrations were measured in a single run using commercially available kits (Human ADP/Acrp30 [adiponectin] enzyme-linked immune-sorbent assay [ELISA] kit and Human Leptin ELISA kit, Elabscience Biotechnology Co., Ltd) according to the manufacturer's instructions. The kit is a direct ELISA for quantitative determination of adiponectin and leptin in human serum, plasma, or other biological fluids. The detection range of serum adiponectin kit was $0.78-50 \mathrm{ng} / \mathrm{ml}$, and the minimum detectable dose of adiponectin was $0.47 \mathrm{ng} / \mathrm{ml}$. The detection range of serum leptin kit was $0.156-10 \mathrm{ng} / \mathrm{ml}$, and the minimum detectable dose of leptin was $0.094 \mathrm{ng} / \mathrm{ml}$. All matched case-control blood samples were handled identically and assayed in the same analytical run.

\section{Statistical analysis}

Mean and frequencies were used to assess the distribution of sample characteristics. Student's $t$-tests and analysis of variance were used to evaluate the differences in adipokine concentrations by categorical variables. Multiple linear regression models were used to investigate the associations between adipokine concentrations and demographic, reproductive, and pathological variables. For all analyses, $P$ values were 2 -sided and $P<0.05$ was considered statistically significant. All statistical tests were done using Data Analysis ToolPak (Microsoft Excel Version 2013).

\section{Results}

The baseline demographic characteristics and reproductive variables of cases and controls are summarized in Table 1. The sociocultural factors unique to the study population are an early age at marriage and first full-term birth, the absence of cases of habitual smoking and alcohol consumption and almost nonexistent oral contraceptive use and hormone replacement therapy. The clinicopathologic characteristics of cases included in the study are summarized in Table 2. The low cancer literacy among Indian women and reluctance to seek immediate medical attention is reflected in the prolonged duration of symptoms (mean \pm standard deviation: $8.27 \pm 13.17$ months).

There was large interindividual variation for serum adipokines, with levels ranging from 3.2 to $15 \mu \mathrm{g} / \mathrm{ml}$ for adiponectin and $0.215-12.15 \mathrm{ng} / \mathrm{ml}$ for leptin. Serum adiponectin levels were reduced significantly in breast cancer patients, in comparison to controls $(P=0.04)$, while serum leptin levels were increased significantly in breast cancer patients, in comparison to controls $(P=0.03)$. ALR was significantly lower in breast cancer cases, in comparison to controls $(P=0.05)$ [Table 3].

Multiple linear regression analysis indicated body mass index (BMI) as the only statistically significant independent correlate of serum adiponectin, serum leptin, and ALR. BMI was negatively correlated to serum adiponectin levels and ALR $(r=0.33, P=0.03 ; r=0.39, P=0.01$, respectively) and positively correlated to serum leptin levels $(r=0.34, P=0.02)$. There was no correlation between receptor status (ER, PR, Her2/neu), aggressiveness of disease in terms of tumor size, nodal metastases, stage, tumor grade, and serum adiponectin levels, leptin levels, or ALR [Table 4].

\section{Discussion}

Obese women have on average a $33 \%$ higher risk of total (95\% confidence interval [CI]: 21\%-47\%) and breast cancer-specific mortality (95\% CI: 19\%-50\%) compared to nonobese women. ${ }^{[6]}$ Adipose tissue is now recognized as metabolically active and a source of adipose tissue-derived hormones and cytokines (adipokines) such as leptin, adiponectin, and inflammatory cytokines.

Elevated leptin levels stimulate breast tumor cell proliferation through several signal transduction pathways and by altering cell-cycle checkpoints via upregulation 


\begin{tabular}{|c|c|c|}
\hline \multicolumn{3}{|c|}{$\begin{array}{c}\text { Table 1: Demographic characteristics and reproductive } \\
\text { variables of cases and controls }\end{array}$} \\
\hline Characteristic & Cases & Controls \\
\hline Number of patients & 40 & 40 \\
\hline Age, mean (range) & $52(25-75)$ & $50(30-70)$ \\
\hline \multicolumn{3}{|l|}{ Education, $n(\%)$} \\
\hline No formal education & $21(52.5)$ & $15(37.5)$ \\
\hline Primary school & $4(10)$ & $6(15)$ \\
\hline Secondary school & $13(32.5)$ & $16(40)$ \\
\hline Graduate & $1(2.5)$ & $1(2.5)$ \\
\hline Postgraduate & $1(2.5)$ & $2(5)$ \\
\hline $\begin{array}{l}\text { Family history of breast cancer/first } \\
\text { degree relative with breast cancer, } n(\%)\end{array}$ & $5(12.5)$ & $2(5)$ \\
\hline $\begin{array}{l}\text { Supplementation of vitamins/ } \\
\text { minerals, } n(\%)\end{array}$ & $5(12.5)$ & $8(20)$ \\
\hline Alcohol consumption, $n(\%)$ & 0 & 0 \\
\hline \multicolumn{3}{|l|}{ Tobacco, $n(\%)$} \\
\hline Smoker & 0 & 0 \\
\hline Gutka chewer & $1(2.5)$ & 0 \\
\hline \multicolumn{3}{|l|}{ Physical activity, $n(\%)$} \\
\hline Mild & $32(80)$ & $29(72.5)$ \\
\hline Moderate & $3(7.5)$ & $5(12.5)$ \\
\hline Vigorous & $5(12.5)$ & $6(15)$ \\
\hline Oral contraceptive pill use, $n(\%)$ & $1(2.5)$ & 0 \\
\hline Hormone replacement therapy, $n(\%)$ & $4(10)$ & 0 \\
\hline \multicolumn{3}{|l|}{ Age at menarche (years), $n(\%)$} \\
\hline$\leq 12$ & $11(27.5)$ & $9(22.5)$ \\
\hline $13-14$ & $24(60)$ & $28(70)$ \\
\hline$\geq 15$ & $5(12.5)$ & $3(7.5)$ \\
\hline \multicolumn{3}{|l|}{ Parity, $n(\%)$} \\
\hline Nulliparous status & $3(7.5)$ & $1(2.5)$ \\
\hline 1 & $1(2.5)$ & $4(10)$ \\
\hline $2-3$ & $23(57.5)$ & $25(62.5)$ \\
\hline$\geq 4$ & $13(32.5)$ & $10(25)$ \\
\hline \multicolumn{3}{|l|}{ Age at first full term birth (years), $n(\%)$} \\
\hline $15-17$ & $15(40.5)$ & $13(33.3)$ \\
\hline $18-20$ & $12(32.4)$ & $10(25.6)$ \\
\hline $21-25$ & $9(24.3)$ & $11(28.2)$ \\
\hline$>25$ & $1(2.7)$ & $5(12.8)$ \\
\hline Breast feeding, $n(\%)$ & $31(77.5)$ & $35(87.5)$ \\
\hline \multicolumn{3}{|l|}{ Age at menopause (years), $n(\%)$} \\
\hline$<45$ & $12(38.7)$ & $12(37.5)$ \\
\hline $45-49$ & $11(35.4)$ & $10(31.2)$ \\
\hline $50-54$ & $8(25.8)$ & $10(31.2)$ \\
\hline$\geq 55$ & 0 & 0 \\
\hline
\end{tabular}

of cyclin D1 and cyclin-dependent kinase 2..$^{[7,8]}$ In contrast to leptin, adiponectin levels are diminished in obesity. Adiponectin via its antagonism of leptin reduces aromatase activity and local estrogen production, signaling through the phosphatidylinositol-3-kinase pathway, and proliferation. ${ }^{[9,10]}$ Adiponectin blocks activation of nuclear factor-kappa B by cytokines such as transforming growth factor- $\alpha$ and thus reduces subsequent production of proinflammatory adipocytokines and insulin resistance. ${ }^{[11]}$ By upregulating peroxisome

\begin{tabular}{|c|c|}
\hline Characteristic & Cases $(n=40)$ \\
\hline $\begin{array}{l}\text { Duration of symptoms (in months), } \\
\text { mean (SD) and range }\end{array}$ & $8.27(13.17)$ and $1-72$ \\
\hline History of benign breast disease, $n(\%)$ & $4(10)$ \\
\hline $\begin{array}{l}\text { Radiation to chest between age } 10 \text { and } \\
30 \text { years, } n(\%)\end{array}$ & 0 \\
\hline \multicolumn{2}{|l|}{ Side, $n(\%)$} \\
\hline Left & $15(37.5)$ \\
\hline Right & $25(62.5)$ \\
\hline \multicolumn{2}{|l|}{ Location if present, $n(\%)$} \\
\hline Upper outer quadrant & $18(45)$ \\
\hline Upper inner quadrant & $6(15)$ \\
\hline Lower outer quadrant & $5(12.5)$ \\
\hline Lower inner quadrant & $2(5)$ \\
\hline Central & $9(22.5)$ \\
\hline \multicolumn{2}{|l|}{ Description of lump, $n(\%)$} \\
\hline Skin changes & $14(35)$ \\
\hline Pain & $8(20)$ \\
\hline Nipple discharge & $4(10)$ \\
\hline Axillary lymphadenopathy & $23(57.5)$ \\
\hline \multicolumn{2}{|l|}{ Stage grouping, $n(\%)$} \\
\hline Stage $0-1 \mathrm{~B}$ & 0 \\
\hline Stage IIA & $10(25)$ \\
\hline Stage IIB & $9(22.5)$ \\
\hline Stage IIIA & $6(15)$ \\
\hline Stage IIIB & $4(10)$ \\
\hline Stage IIIC & $5(12.5)$ \\
\hline Stage IV & $6(15)$ \\
\hline \multicolumn{2}{|l|}{ Hormonal receptor status } \\
\hline ER positive & $21(52.5)$ \\
\hline PR positive & $15(37.5)$ \\
\hline Her2/neu positive (IHC) & $9(22.5)$ \\
\hline Her2/neu positive (FISH) & $2(5)$ \\
\hline \multicolumn{2}{|l|}{ Grade } \\
\hline 1 & 0 \\
\hline 2 & $13(32.5)$ \\
\hline 3 & $15(37.5)$ \\
\hline
\end{tabular}

Her2 - Human epidermal growth factor receptor 2;

ER - Estrogen receptor; PR - Progesterone receptor;

IHC - Immunohistochemistry; FISH - Fluorescence in situ hybridization; SD - Standard deviation

proliferator-activated receptor- $\gamma$, which forms heterodimers with the retinoid X-receptor, adiponectin promotes differentiation and apoptosis through p53-dependent mechanisms. ${ }^{[12]}$ Finally, adiponectin upregulates the tumor suppressor liver kinase B1 and increases 5' adenosine monophosphate-activated protein kinase, which in turn blocks activation of the mammalian target of rapamycin pathway and reduces motility and angiogenesis. ${ }^{[13]}$

Serum adiponectin levels and ALR were significantly reduced whereas serum leptin levels were increased in breast cancer cases in comparison to controls which were in agreement with previous studies. ${ }^{[3,5]}$ The mean adiponectin 
levels of cases $(8.69 \mu \mathrm{g} / \mathrm{ml} \pm 2.95)$ in the present study were comparable to other studies $(2-20 \mu \mathrm{g} / \mathrm{mL}) \cdot{ }^{[14,15]}$ However, the optimal level of adipokines for breast health and levels that should be considered unhealthy have not been established and vary by race and assay methodology. ${ }^{[16]}$

Neither receptor status (ER, PR, and HER-2/neu receptor) nor aggressiveness of disease (tumor size, nodal metastases, stage, and grade) had an effect on the serum adiponectin levels, leptin levels, or ALR in cases. Some but not all studies have suggested that breast tumors arising in women with hypoadiponectinemia may present a more aggressive phenotype (large size of tumor, higher histological grade, and ER negativity). ${ }^{[17-19]}$ Studies have found a significant association of serum adiponectin with either receptor-negative breast cancer $^{[18,20]}$ or receptor-positive breast cancer. ${ }^{[21]}$ However, there are several studies which have found no significant associations in regard to hormonal receptor status. ${ }^{[22,23]}$

BMI was negatively correlated with serum adiponectin levels and ALR and positively correlated with serum leptin levels and was the only statistically significant independent correlate. In other words, the association of serum adiponectin and serum leptin levels with breast cancer was not independent of measures of adiposity in the present study.

\section{Limitations}

The cross-sectional design of this study meant that there was a potential for selection bias, particularly in the selection

\begin{tabular}{lccc}
\hline \multicolumn{3}{c}{ Table 3: Adipokine levels in cases and controls } \\
\hline Characteristic & Cases & Controls & $\boldsymbol{P}$ \\
\hline $\begin{array}{l}\text { Serum adiponectin }(\mu \mathrm{g} / \mathrm{ml}), \\
\text { mean (SD) }\end{array}$ & $8.69(2.95)$ & $10.15(3.56)$ & 0.04 \\
$\begin{array}{l}\text { Serum leptin }(\mathrm{ng} / \mathrm{ml}), \\
\text { mean (SD) }\end{array}$ & $7.93(2.90)$ & $6.26(3.86)$ & 0.03 \\
$\begin{array}{l}\text { Adiponectin leptin ratio, } \\
\text { mean (SD) }\end{array}$ & $1.91(3.17)$ & $5.76(11.92)$ & 0.05 \\
\hline
\end{tabular}
SD - Standard deviation of controls. However, controls came from the same study base as our cases and criteria for inclusion and exclusion were strictly adhered to minimize any influence on results of the study. It has been hypothesized that adiponectin may exert carcinogenic effects through modulation of insulin sensitivity. ${ }^{[3]}$ Therefore, another limitation of this study is the lack of information on insulin levels in cases and controls. The results of the study are based on a one-time measurement of serum adipokine levels. However, previous studies have confirmed the stability and reliability of a one-time measure to be high. ${ }^{[2]}$ Another limitation of this study is its small sample size.

\section{Recommendations for future work}

The foremost reason why investigators have been attempting to accurately define the link between obesity and breast cancer is understanding that it offers an opportunity at chemoprevention. The interventions that have been tested to raise adiponectin, particularly for overweight or insulin-resistant individuals, include, encouraging weight loss, ${ }^{[25]}$ bariatric surgery, ${ }^{[26]}$ antidiabetic drugs of the thiazolidinedione class, ${ }^{[27]}$ lipid-lowering drugs including statins, ${ }^{[28]}$ omega-3 fatty acids, ${ }^{[29]}$ and fibrates, ${ }^{[30]}$ antihypertensives such as angiotensin-converting enzyme inhibitors $^{[31]}$ and beta blockers. ${ }^{[32]}$

\section{Conclusion}

In summary, our results suggest that low serum adiponectin levels, low ALR and high serum leptin levels are associated with breast cancer. BMI was the only statistically significant independent correlate of serum adiponectin, serum leptin and ALR. The inconsistencies in data attempting to define the relationship between obesity and breast cancer reinforce the complexity and multifactorial nature of the relationship.

\section{Financial support and sponsorship}

Nil.

Table 4: Multiple linear regression analysis with serum adiponectin, leptin, and adiponectin-leptin ratio as the independent variables

\begin{tabular}{|c|c|c|c|c|c|c|c|c|c|}
\hline \multirow[t]{2}{*}{ Variable } & \multicolumn{3}{|c|}{ Adiponectin $(\mu \mathrm{g} / \mathrm{ml})$} & \multicolumn{3}{|c|}{ Leptin $(\mathrm{ng} / \mathrm{ml})$} & \multicolumn{3}{|c|}{ Adiponectin leptin ratio } \\
\hline & $\begin{array}{l}\text { Correlation } \\
\text { coefficient }(r)\end{array}$ & SE & $P$ & $\begin{array}{l}\text { Correlation } \\
\text { coefficient }(r)\end{array}$ & SE & $P$ & $\begin{array}{l}\text { Correlation } \\
\text { coefficient }(r)\end{array}$ & $\mathbf{S E}$ & $\boldsymbol{P}$ \\
\hline ER status & 0.21 & 2.91 & 0.17 & 0.200 & 2.885 & 0.211 & 0.22 & 3.12 & 0.15 \\
\hline PR status & 0.15 & 2.95 & 0.33 & 0.160 & 2.907 & 0.321 & 0.25 & 3.1 & 0.11 \\
\hline Her2/neu receptor status & 0.03 & 2.98 & 0.83 & 0.030 & 2.944 & 0.851 & 0.09 & 3.19 & 0.54 \\
\hline Grade & 0.17 & 2.94 & 0.27 & 0.195 & 2.889 & 0.226 & 0.12 & 3.18 & 0.42 \\
\hline Stage & 0.12 & 2.96 & 0.43 & 0.130 & 2.920 & 0.422 & 0.02 & 3.21 & 0.87 \\
\hline Tumour size & 0.13 & 2.96 & 0.41 & 0.167 & 2.904 & 0.301 & 0.29 & 3.07 & 0.06 \\
\hline Nodal status & 0.1 & 2.97 & 0.53 & 0.055 & 11.860 & 0.735 & 0.1 & 3.19 & 0.53 \\
\hline BMI & 0.33 & 2.82 & $0.03 *$ & 0.346 & 2.763 & $0.028 *$ & 0.39 & 2.94 & $0.01 *$ \\
\hline Physical activity & 0.12 & 2.96 & 0.42 & 0.133 & 2.919 & 0.411 & 0.12 & 3.18 & 0.44 \\
\hline Parity & 0.09 & 2.97 & 0.57 & 0.087 & 2.934 & 0.589 & 0.2 & 3.14 & 0.2 \\
\hline
\end{tabular}

SE - Standard error; Her2 - Human epidermal growth factor receptor 2; ER - Estrogen receptor; PR - Progesterone receptor; BMI - Body mass index; $* P$ value for BMI 


\section{Conflicts of interest}

There are no conflicts of interest.

\section{References}

1. Cleary MP, Grossmann ME. Minireview: Obesity and breast cancer: The estrogen connection. Endocrinology 2009;150:2537-42.

2. Park J, Morley TS, Kim M, Clegg DJ, Scherer PE. Obesity and cancer-Mechanisms underlying tumour progression and recurrence. Nat Rev Endocrinol 2014;10:455-65.

3. Kelesidis I, Kelesidis T, Mantzoros CS. Adiponectin and cancer: A systematic review. Br J Cancer 2006 8;94:1221-5.

4. Schmidt S, Monk JM, Robinson LE, Mourtzakis M. The integrative role of leptin, oestrogen and the insulin family in obesity-associated breast cancer: Potential effects of exercise. Obes Rev 2015;16:473-87.

5. Cleary MP, Ray A, Rogozina OP, Dogan S, Grossmann ME. Targeting the adiponectin: Leptin ratio for postmenopausal breast cancer prevention. Front Biosci (Schol Ed) 2009;1:329-57.

6. Chan DS, Vieira AR, Aune D, Bandera EV, Greenwood DC, McTiernan A, et al. Body mass index and survival in women with breast cancer-systematic literature review and meta-analysis of 82 follow-up studies. Ann Oncol 2014;25:1901-14.

7. Jardé T, Perrier S, Vasson MP, Caldefie-Chézet F. Molecular mechanisms of leptin and adiponectin in breast cancer. Eur $\mathrm{J}$ Cancer 2011;47:33-43.

8. Okumura M, Yamamoto M, Sakuma H, Kojima T, Maruyama T, Jamali $\mathrm{M}$, et al. Leptin and high glucose stimulate cell proliferation in MCF-7 human breast cancer cells: Reciprocal involvement of PKC-alpha and PPAR expression. Biochim Biophys Acta 2002;1592:107-16.

9. Wang $\mathrm{Y}, \mathrm{Lam} \mathrm{KS}, \mathrm{Xu} \mathrm{A}$. Adiponectin as a negative regulator in obesity-related mammary carcinogenesis. Cell Res 2007; 17:280-2.

10. Jardé T, Caldefie-Chézet F, Goncalves-Mendes N, Mishellany F, Buechler C, Penault-Llorca F, et al. Involvement of adiponectin and leptin in breast cancer: Clinical and in vitro studies. Endocr Relat Cancer 2009;16:1197-210.

11. Hattori Y, Nakano Y, Hattori S, Tomizawa A, Inukai K, Kasai K. High molecular weight adiponectin activates AMPK and suppresses cytokine-induced NF-kappaB activation in vascular endothelial cells. FEBS Lett 2008;582:1719-24.

12. Rahal OM, Simmen RC. Paracrine-acting adiponectin promotes mammary epithelial differentiation and synergizes with genistein to enhance transcriptional response to estrogen receptor $\beta$ signaling. Endocrinology 2011;152:3409-21.

13. Vona-Davis L, Rose DP. Angiogenesis, adipokines and breast cancer. Cytokine Growth Factor Rev 2009;20:193-201.

14. Ryan AS, Berman DM, Nicklas BJ, Sinha M, Gingerich RL, Meneilly GS, et al. Plasma adiponectin and leptin levels, body composition, and glucose utilization in adult women with wide ranges of age and obesity. Diabetes Care 2003;26:2383-8.

15. Grossmann ME, Ray A, Nkhata KJ, Malakhov DA, Rogozina OP, Dogan S, et al. Obesity and breast cancer: Status of leptin and adiponectin in pathological processes. Cancer Metastasis Rev 2010;29:641-53.

16. Aguilar-Salinas CA, García EG, Robles L, Riaño D,
Ruiz-Gomez DG, García-Ulloa AC, et al. High adiponectin concentrations are associated with the metabolically healthy obese phenotype. J Clin Endocrinol Metab 2008;93:4075-9.

17. Mantzoros C, Petridou E, Dessypris N, Chavelas C, Dalamaga M, Alexe DM, et al. Adiponectin and breast cancer risk. J Clin Endocrinol Metab 2004;89:1102-7.

18. Miyoshi Y, Funahashi T, Kihara S, Taguchi T, Tamaki Y, Matsuzawa Y, Noguchi S. Association of serum adiponectin levels with breast cancer risk. Clin Cancer Res 2003;9:5699-704.

19. Chen DC, Chung YF, Yeh YT, Chaung HC, Kuo FC, Fu OY, et al. Serum adiponectin and leptin levels in Taiwanese breast cancer patients. Cancer Lett 2006;237:109-14.

20. Oh SW, Park CY, Lee ES, Yoon YS, Lee ES, Park SS, et al. Adipokines, insulin resistance, metabolic syndrome, and breast cancer recurrence: A cohort study. Breast Cancer Res 2011;13:R34.

21. Tian YF, Chu CH, Wu MH, Chang CL, Yang T, Chou YC, et al. Anthropometric measures, plasma adiponectin, and breast cancer risk. Endocr Relat Cancer 2007;14:669-77.

22. Tworoger SS, Eliassen AH, Kelesidis T, Colditz GA, Willett WC, Mantzoros CS, et al. Plasma adiponectin concentrations and risk of incident breast cancer. J Clin Endocrinol Metab 2007;92:1510-6.

23. Cust AE, Stocks T, Lukanova A, Lundin E, Hallmans G, Kaaks $\mathrm{R}$, et al. The influence of overweight and insulin resistance on breast cancer risk and tumour stage at diagnosis: A prospective study. Breast Cancer Res Treat 2009;113:567-76.

24. Pischon T, Hotamisligil GS, Rimm EB. Adiponectin: Stability in plasma over 36 hours and within-person variation over 1 year. Clin Chem 2003;49:650-2.

25. Weiss EP, Racette SB, Villareal DT, Fontana L, Steger-May K, Schechtman $\mathrm{KB}$, et al. Improvements in glucose tolerance and insulin action induced by increasing energy expenditure or decreasing energy intake: A randomized controlled trial. Am J Clin Nutr 2006;84:1033-42.

26. Christou NV, Lieberman M, Sampalis F, Sampalis JS. Bariatric surgery reduces cancer risk in morbidly obese patients. Surg Obes Relat Dis 2008;4:691-5.

27. Westerink J, Visseren FL. Pharmacological and non-pharmacological interventions to influence adipose tissue function. Cardiovasc Diabetol 2011;10:13.

28. Wanders D, Plaisance EP, Judd RL. Pharmacological effects of lipid-lowering drugs on circulating adipokines. World J Diabetes 2010;1:116-28.

29. Banga A, Unal R, Tripathi P, Pokrovskaya I, Owens RJ, Kern PA, et al. Adiponectin translation is increased by the PPARgamma agonists pioglitazone and omega-3 fatty acids. Am J Physiol Endocrinol Metab 2009;296:E480-9.

30. Oki K, Koide J, Nakanishi S, Nakashima R, Yamane K. Fenofibrate increases high molecular weight adiponectin in subjects with hypertriglyceridemia. Endocr J 2007;54:431-5.

31. Storka A, Vojtassakova E, Mueller M, Kapiotis S, Haider DG, Jungbauer A, Wolzt M. Angiotensin inhibition stimulates PPARgamma and the release of visfatin. Eur $\mathrm{J}$ Clin Invest 2008;38:820-6.

32. Nakamura T, Kawachi K, Saito Y, Saito T, Morishita K, Hoshino J, et al. Effects of ARB or ACE-inhibitor administration on plasma levels of aldosterone and adiponectin in hypertension. Int Heart J 2009;50:501-12. 